\title{
مسألة الحرية في النظام السياسي الإسلامي
}

\section{رحيل محمد غرايبة* - ت}

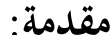

تمدف هذه الدراسة إلى حل إثكالية الحرية والسلطة في النظام السياسي الإسلامي، لإبراز فلسفة الإسلام في التعامل مع الحرية عبر قوة السلطة وقوة التنفيذ والتطبيق. وليس مقصود الدراسة الحديث حول الحريات السياسية في النظام السياسي الإسلامي، وإنما الحديث عن مبدأ الحرية في قواعد النظام السياسي الإسلامي، ومبدأ الحرية في مقاصده وغاياته وواجباته التشريعية.

إن نظرة الإسلام للحرية وفلسفته في التعامل معها توضح البعد الفلسفي العميق لتعامل الإسلام مع الحرية المركوزة في الفطرة الإنسانية والتي تعدّ مناط الابتلاء الرباني للمكلف للإنسان، فمشيئة الله التي قضت باختيار الإنسان ليحمل الأمانة أفضت أن يكون حراً، مطلق الإرادة، غير مقهور كبقية المخلوقات التي تمارس عبوديتها لله بلا إرادة أو ابتلاء.

وفي مقابل ذلك اقتضت ضرورة التجمع البشري وجود أنظمة شرعية تعالج الآثار المترتبة على هذا التجمع من التزاحم والتنافس والتخاصم، الذي يقتضي وجود سلطة تأمر وتنهى وتزجر وتحاسب وتعاقب

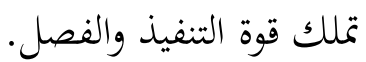

ويمكن تمثيل العلاقة الجدلية بين الفرد والمجتمع من جهة وبين السلطة والحرية من جهة أخرى مع ما بينها جميعاً من علاقة متبادلة كما يلي: 


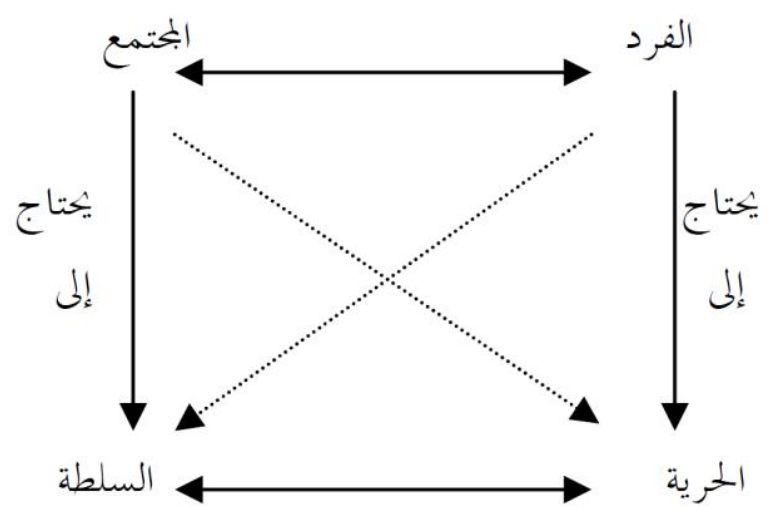

وتتميز هذه الدراسة عما سبقها من دراسات في هذا المجال، أها حاولت التركيز على حل إشكالية العلاقة الجدلية بين السلطة والحرية في النظام السياسي الإسلامي حلاً يقوم على فهم الفلسفة التشريعية والمرتبة المقاصدية للحرية في الإسلام.

ولذلك تم الحديث أولاً عن أهمية الحريّة وضرورتما في الفقه الإسلامي والشريعة الإسلامية. وبيان المرتبة المقاصدية لها بين مقاصد الشريعة المتفق عليها. ثم بعد ذلك الوقوف على أهم المقاصد التشريعية للنظام السياسي وواجب السلطة وما وضعت له من وجهة نظر تشريعية إسلامية، وعلاقة هذا المقصد بالحريّة الإنسانية.

\section{أولاً :مفهوم الحرية وأهميتها في الفقه الإسلامي}

كلمة الحرية مأخوذة من حرّ يحر إذا صار حرّاً، والاسم: حريّة، وحرّره: أعتقه، والحر من الناس: أخيارهم وأفاضلهم وأشرافهم. والحرّ: الفعل الحسن، والحرّة من النساء: الكريمة الشريفة. وسحابة حرّة: بكرٌّ كثيرة المطر.

واستخدام العرب للفظ الحرية ومشتقاتما يأتي بمعان حسنة جميلة، فإذا وصف الإنسان بأنه حرّ: أي أنه لا يقبل الضيم وينأى عن الأفعال الخسيسة، وكذلك المرأة إذا قيل أها حرّة: أي أها من أصل طيب ومنبت حسن ونسب أصيل، كما أها تحافظ على سمعتها وشرفها فيقولون هي من نسب حرّ، أو من أحرار

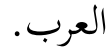

$$
1 \text { 1 ابن منظور، لسان العرب، مادة "حرر"، والفيروز آبادي، مجد الدين محمد بن يعقوب، القاموس المخيط. }
$$


وقد ورد في كتب الحديث الصحاح أن الرسول صلى الله عليه وسلم أخذ البيعة من النساء على أن لا يشركن بالله شيئاً، ولا يقتلن أولادهن، ولا يزنين..." فقالت هند بنت عتبة مخاطبة الرسول صلى الله عليه

كما ورد من حكم العرب المأثورة: "الحرّ من راعى وداد لحظة، وانتمى لمن أفاده لفظة."3 بمعنى من صفات الحرّية في الإنسان أن يكون وفياً، لا ينسى المعروف ولا ينسى المودة، حتى لو كانت لبرهة من الوقت "وداد لحظة." كما أنه يقدر معلمه وأستاذه ويقابل ذلك بالاحترام والوفاء لما أسدى له من نعمة التعلم، مهما كان قليلاً، ولو لمجرد "لفظة."

وقد تعددت المذاهب في تعريف الحرية، واختلفت الآراء وتباينت تبايناً شديداً في تحديد مصطلح منضبط للحرية، ولا يتسع المجال لاستقصائه، وإنما يمكن اختيار بعض التعريفات. فقد ورد في إعلان حقوق الإنسان الصادر عام 1789: "الحرية هي حق الفرد في أن يفعل ما لا يضر بالآخرين."4 وعرفها لوك (Locke) بأها: الحق في فعل أي شيء تسمح به القوانين."5

أما عن تعريف الحرّية في الفقه الإسلامي، فيمكن الوقوف على تعريف الدريني الذي يقول فيه: "الحرية هي المكنة العامة التي قررها الشارع للأفراد على السواء، تمكيناً لمم من التصرف على خيرة من أمرهم دون الإضرار بالغير."6 مستنداً على تعريف الفقهاء لمعنى الإباحة التي تقوم في أصل تشريعها على التخيير بين

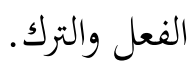


وقد ذهب الفاسي إلى محاولة التفريق بين نظرة الإسلام إلى الحرية ومفهومها عن كل النظريات الأخرى الفلسفية والاشتراكية والمادية الغربية بأن يقول: "الحرية جعل قانوني وليس حقاً طبيعياً، فما كان للإنسان

$$
\text { ليصل إلى حريته لولا نزول الوحي، وأن الإنسان لم يخلق حراً، وإنما ليكون حرًا."7 وقائ. }
$$

وأجد نفسي ميالاً إلى المفهوم الذي يجعل الحرية أصلاً مركوزاً في فطرة الإنسان، وجعلها مناط الابتلاء، كما جعل العقل مناط التكليف، فالله عز وجل الذي خلق الإنسان وكونه أراده عاقلاً حراً، ثم أناط به الخلافة في الأرض وإعمارها وفق منهج تشريعي عبادي متسق مع نواميس الكون وحركة الموجودات. ونقصد بالحرية في هذه الدراسة ما وهبه الله للإنسان من مكنة التصرف لاستيفاء حقه وأداء واجبه دون تعسف أو اعتداء.

وسوف تكون معالجة مضمون البحث قائماً على هذا المفهوم في مختلف الجزئيات.

وفيما يتعلق بأهمية الحرية في الفقه الإسلامي، فقد خلق الله الإنسان بهذا التكوين الفريد المقصود، من أجل إعداده للقيام بالغاية والمهمة التي أرادها الله عز وجل.

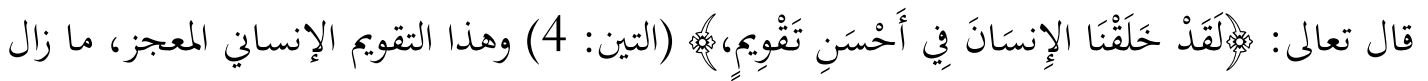
محل دراسة وبحث، واختلفت النظريات وتعددت في فهمه وتحليل مكنونه، وما زالت بعض تكوينات الإنسان

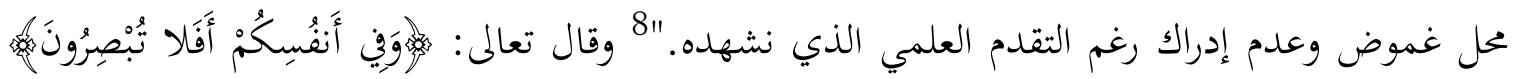

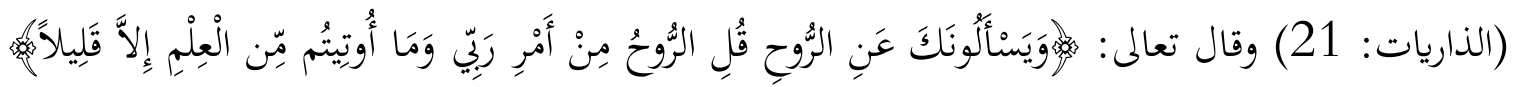

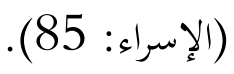

وما نقصده هنا أن الله عز وجل خلق الإنسان مجبولاً على الحرية يتوق إليها أكثر من توقه إلى الطعام والشراب وبقية الحاجات، ونرى أن الإنسان يضحي بحاجات كثيرة من أجل الحصول على حريته والتمتع بها.

$$
8 \text { ت } 7
$$


فهي ترقى إلى مرتبة الضرورة لديه. ومصادرة الحرية من الإنسان هي عقوبة يستحقها عند المخالفة فلا يجوز

$$
\text { تقييد حريته إلا بسبب مشروع. }
$$

ولذلك فإن حق الإنسان في الحرية وإطلاق الإرادة، حق مقدس، لأن الله عز وجل هو الذي منحه هذا الحق، ولا يملك أحد من البشر نزعه أو إعدامه. وقد قال عمر بن الخطاب رضي الله عنه معبراً عن هذه الحقيقة: "متى استعبدتم الناس وقد ولدقم أمهاقم أحراراً."9 وأصبحت هذه العبارة قاعدة هادية للبشرية للتعامل مع الحقوق الإنسانية في كل العصور، وارتكز عليها ميثاق حقوق الإنسان الشهير الصادر عن هيئة

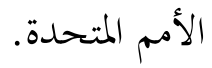

وعلى هذا النحو فإن المحافظة على الإنسان وحقوقه والتي هي وظيفة كل سلطة وكل نظام دنيوي يقتضي الحفاظ على حرّيته، لأن الحريّة تسبق الإرادة في ممارسة الإنسان ألوان نشاطه الطبيعي، فيما يأكل ويشرب، ويلبس ويتعلم ويعمل ويسير، ويبني أسرته، ويرعى أبناءه، ويعمر أرضه، ويدفع عن نفسه.

ولقد جعل أبو حنيفة حرية الإنسان مقدمة على المال، عندما منع الحجر على السفيه إذا بلغ عاقلاً، لأن الحجر عليه إهدار لكرامته وإنسانيته، وإلحاقه بالصبيان والمجانين والبهائم، وهو ضرر يفوق الضرر

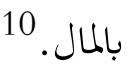

وكذلك خلق الله الإنسان لحمل أمانته فأكرمه بالعقل والذمة، وأثبت له حق العصمة والحرية، قال

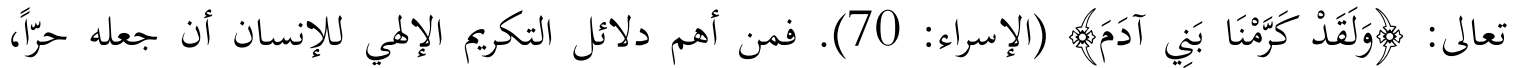
وجعل الحرية من مقتضيات الفطرة البشرية وتلبية لأشواقها الأصيلة في البحث عن الحقيقة والوصول إلى

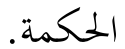

ابن الجوزي، أبو الفرج عبد الرحمن بن علي، مناقب أمير المؤمنين عمر بن الخطاب، تحقيق زينب إبراهيم القاروط، بيروت: دار الكتب

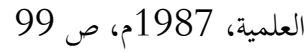

البخاري، عبد العزيز بن أحمد. كشف الأسرار عن أصول فخر الإسلام البزدوي، تحقيق محمد المعتصم بالله البغدادي، بيروت: دار

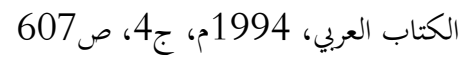


ولا تتحقق كرامة الإنسان المقصودة والشارع إلا بمنحه حريته، التي تكمل معنى سيادته في الكون وتحميله وظيفته ومسؤوليته الكبرى، إذ لا سيادة بلا حرّية، لأن السيادة تقتضي إطلاق قواه الظاهرة والباطنة في الاستكشاف والاستخلاف.11

ويتضح معنى الحرية التكريكي بتحرير الإنسان من نوازع الطغيان ودواعي الهوى في نفسه أولاً، فلا يجوز أن يتبادر إلى بعض الأذهان أن الحرية تعني الاستجابة المطلقة لرغبات النفس ودواعي الهوى والشهوة. بل إن

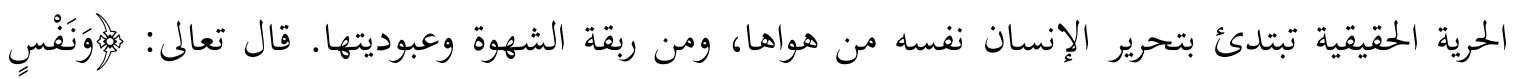

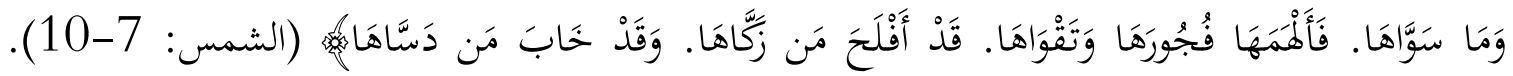
وجوهر تزكية النفس يقوم على تحريرها من الموى، والذي يتحقق بعبادة الله كما أمر وكما شرع. 12 كما يتضح ذلك بتحرير الإنسان من الخوف على أجله ورزقه، عبر عقيدة المؤمن الراسخة المنطلقة من

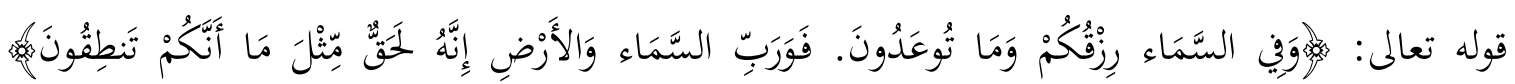

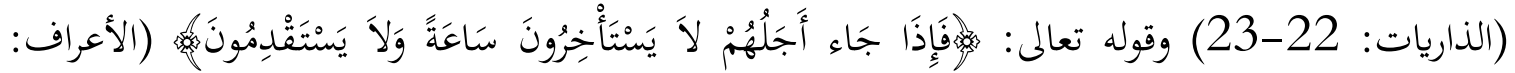

يقول سيد قطب: "ويعرف أن المقصود بها ليس هو إهمال الأرض وأسباهما، فهو مكلف بالخلافة فيها وتعميرها، إنما المقصود هو إلا يعلق نفسه بها، وإلا يغفل عن الله في عمارتا، ليعمل في الأرض وهو يتطلع إلى السماء، وبذلك ينطلق قلبه من اسار الأسباب الظاهرة ويعيش موصولاً قلبه بالسماء، وقدماه ثابتتان على الأرض، فهكذا يريد الله الإنسان لذذا المخلوق الذي جبله من طين ونفخ فيه من روحه، فإذا هو مفضل على كثير من العالمين والإيمان هو الوسيلة لتحقيق ذلك الوضع الذي يكون فيه الإنسان في أفضل حالاته، لأنه يكون في الحالة التي أنشأه الله لما، فطرة الله التي فطر الله الناس عليها. "13

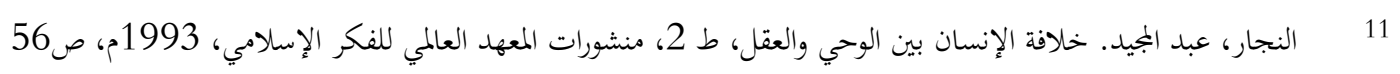

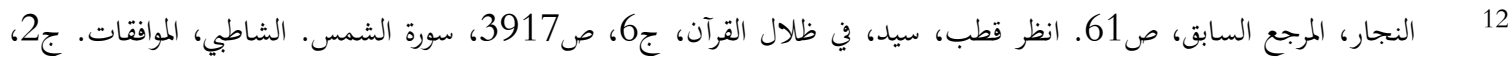

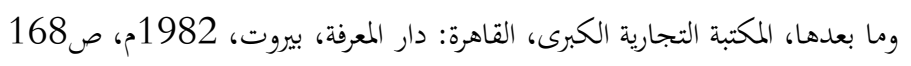

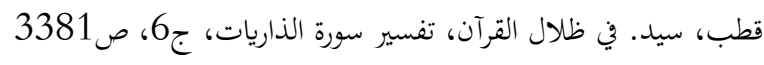


ويدخل في المعنى التكريمي للحرية تحرير الإنسان من العبودية لغير الله، فاستعباد البشر للبشر أبشع أنواع العبودية وأظلمها، وقد قرر الله عز وجل أن جميع الناس خلقوا من أصل واحد، فلا يجوز أن يستعلي جنس على جنس، أو عنصر على عنصر، أو طبقة على طبقة، لأن ذلك إهانة للجنس البشري، وإهانة لإنسانية الإنسان.

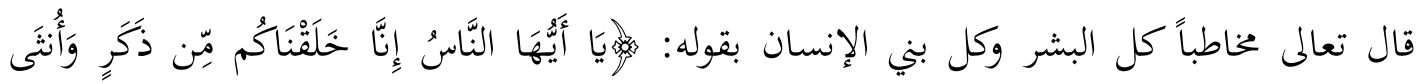

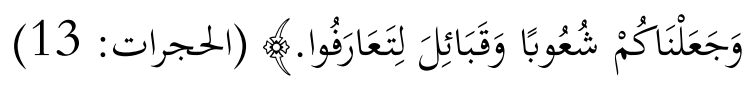

إن هذه الآية تقرر تكريم الإنسان بصفته الآدمية، والتي تحرّم كل أشكال الاستعباد والقهر والاستعلاء

$$
\text { والطغيان من الإنسان لأخيه الإنسان. }
$$

وأخيراً فإن من معاني التكريم تحرير العقل الإنساني من الخرافات والأساطير، وكل الأباطيل التي تضلل العقل وتصرفه عن الحق ولا تمديه إلى الصواب من القول والفعل ولا تؤدي به إلى طريق الرشاد. قال تعالى:

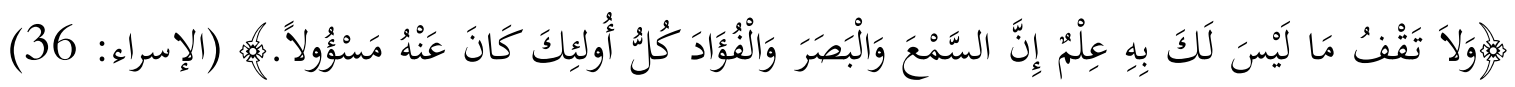
وقال أيضاً:

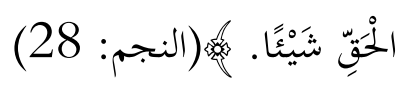

إن هذه الحرية التكريمية التي قررها الإسلام للإنسان في عقله وإرادته ونفسه وقواه كلها، تصلح لبناء قاعدة قطعية في تنظيم التجمع البشري وهادياً للنظام السياسي والإداري في كيفية التعامل مع الحرية الإنسانية.

ونجد أن القرآن الملكي كان يهدف في أول ما يهدف إلى تحرير العقل من كل ما يصرفه عن التفكير الصحيح، وكل ما يعطله عن واجبه الحقيقي في الوصول إلى الحق.

وترتبط الحرية في مفهومها الإسلامي بمبدأ الخلافة في الأرض، فقد خلق الله الإنسان وأعده ليكون قادراً على حمل الأمانة التي أنيط الإنسان بها. 


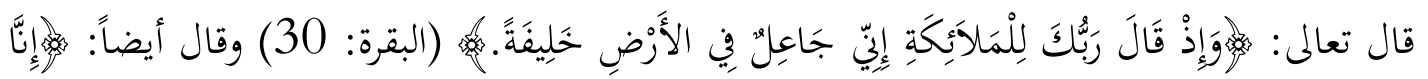

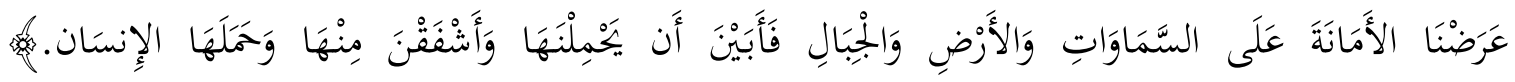
(الأحزاب: 72) فموجودات الكون التي تقوم بدورها مقهورة، لا تصلح لحمل الأمانة ولا القيام بمهمة الخلافة عن الله في الأرض، فميزة الإنسان الواضحة عنها هي أنه ليس مقهوراً، فقد أكرمه الله بالعقل والحرية. وحرية الإرادة هي السبيل الوحيد إلى الترقي والاكتمال في منهج العبودية الذي يمكنه من السموّ النفسي نحو الأفق الإلهي العلوي، على سبيل الإدراك والفهم والاستيعاب والتحمل لأمر الله وغهيه فيما يمكنه من مباشرة التفاعل مع الكون تفاعلاً صحيحاً، يقوم على أسس وقواعد سليمة، لا تدرك إلا من خلال الوحي.14

فالإنسان الحر، هو وحده القادر على إطلاق عقله وروحه، بمحض اختياره القائم على فهم خطاب الخالق، الذي يمكنه من فهم أسرار الكون والتعامل معها عبر ضرب من المجاهدة، التي ترتفع بإنسانيته ووجوده ليصبح المخلوق الأعظم في الكون، الذي تكفل الله له بتسخير ما في السموات والأرض من أجل القيام بمهمته في إعمار الكون وإصلاح الأرض، ورعاية الكائنات وفقاً لمنهج الله المستقيم.

وإذا تخلى الإنسان عن هذا المنهج، ورضي بالارتكاس في مهاوي الظلم والاستعباد فسوف تكون العاقبة ظهور الفساد في البر والبحر. ومن هنا يجب على أصحاب منهج خلافة الله في أرضه وفق أوامر الوحي أن يعمدوا إلى تحرير البشرية من كل أشكال الاستعباد وألوانه، قبل مباشرة الخطاب والدعوة.

وترتبط الحرية كذلك بمبدأ التكليف فقد اتفق الفقهاء أنه لا تكليف إلا من العقل، وهذا لا يحتاج إلى دليل، لأن الخطاب التكليفي متوجه إلى العقلاء.

ويمكن القول أيضاً أنه لا تكليف إلا مع الإرادة، ولا معنى لتكليف العبد إذا كان مسلوب الإرادة فاقد الحرية. ويمكن الوقوف على هذا المعنى من خلال الوقوف على معنى الابتلاء، إذ أن التكليف مصحوب

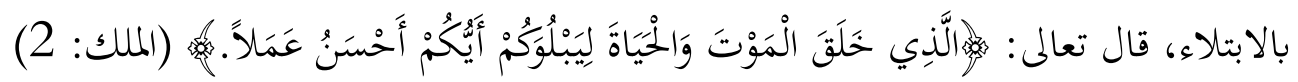

$$
14
$$


فقد قضى حكم الله أن يجعل تكليف الناس قائماً على اختبارهم في الحياة الدنيا، بحيث يكون الجزاء في الآخرة بحسب البذل في الدنيا. إذ ليس من العدل أن يكلف الله الناس بالعمل تم يجعلهم مقهورين، فلا بد من استواء معنى الابتلاء توفر حرّية المكلف وقدرته على الاختيار. كما أن حكمة الابتلاء تتجلى في حدوث الإعمار على أكمل وجوهه، إذ أن الجهد الإنساني يصل

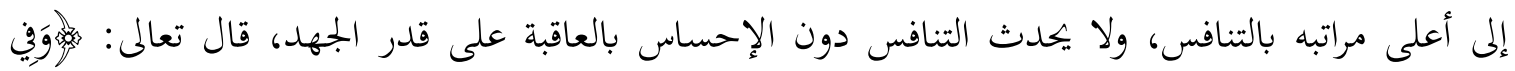

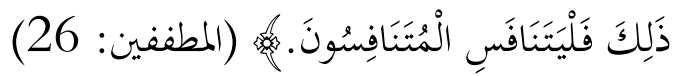

فلو تساوى أجر المجتهد والكسول، والعامل والساكن، والمجاهد والقاعد، لانعدم التنافس، وترهل الجههد البشري، وانتكس العمل ولكان ذلك مدعاة إلى الخمول والتخلف والهلاك لا محالة.

ولا طريق إلى التنافس الخيّر إلا إذا توافرت الحرّية البشرية الكافية لإطلاق الجهد في الإعمار والإصلاح. والحرية الكاملة التي توصل إلى معرفة الخطأ، والصواب، وتمكين العباد من إصلاح الخلل على مستوى الفرد والجماعة. وقد لوحظ أن قدرة الإنسان على الإبداع والاختراع والترقي في العمران والحضارة ترتبط بمقدار ما يتمتع به من حرية، فمن مقتضيات الخلافة والقيام بها على الوجه المقصود من الشارع يقتضي استخدام العقل والملكات الإنسانية في تطوير الوسائل والأساليب التي تحقق أقصى غايات الإتقان والإحسان في العمل وهذا يقوم على إطلاق العنان للعقل الإنساني في التفكير والتدبر والبحث في سنن الكون ونواميسه من أجل الاكتشاف والتسخير، ويقوم على إطلاق العنان للمنافسة بين العقول البشرية عبر الأجيال من أجل التسابق إلى الاستحواذ على الحكمة وقطف ثمار الجهد البشري المتراكم في التحسين والتطوير وحسن الأداء، بما يوفر الوقت والجهاد البشري، ويقوم كذلك على إطلاق العنان للعقول في الحوار والاتصال والجدال بالتي هي أحسن من أجل معرفة الصواب والخطأ، والقدرة على التقويم، وتعزيز التجارب الناجحة، ومقاومة الخلل وإصلاح الخطأ.

الريسوني، أممد. إنسانية الإنسان قبل حقوق الإنسان، بحث في كتاب: حقوق الإنسان بين الشريعة والقانون، ص58، كتاب الأمة، 2002م، وزارة الأوقاف، قطر. 
وكل ما ذكر سابقاً، لا يتم إلا "بالحرية" الإنسانية الواسعة التي توفر انطلاق العقل والإرادة في كل مجالات الحياة السياسية والاقتصادية والاجتماعية على مستوى الفرد والجماعة.

وإن التجارب البشرية تعزز هذا المعنى قديماً وحديثاً، فعندما ينعم الناس بالحرية ويحسون بالأمن على أنفسهم وأموالهم وأبنائهم، يسود الاستقرار والعمران، ويكثر الخصب، ويسود الرفاه، وينتشر العلم، وتتطور المعرفة. وعندما يسود الظلم والكبت والقمع، وتصادر الحرية، ينتشر الخوف والقلق وتنتفي الطمأنينة وينعدم دور العقل، ويضعف العلم، ويعم الجهل ويظهر الفساد، فيسود التخلف، وترتكس الحياة، وتعود البشرية في

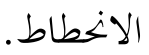

وهذا ما نشاهده عياناً في الدول المتقدمة وفي الدول المتخلفة، ويمكن القول إن الإبداع والتطور والرقي الحضاري والعمران البشري يتناسب طردياً مع منسوب الحرية الإنسانية المتوافرة في جميع مجالات الحياة وعلى جميع أصعدة العمل والإنتاج. وترتبط عملية التغيير الاجتماعي التي يهدف إلى تحقيقها الإسلام عبر الجهد الدعوي الذي يمارسه التجمع المسلم بشكل فردي وجماعي، ارتباطاً وثيقاً بتحقق الحرية للفرد وللجماعة. ويمكن اشتقاق هذا المعنى

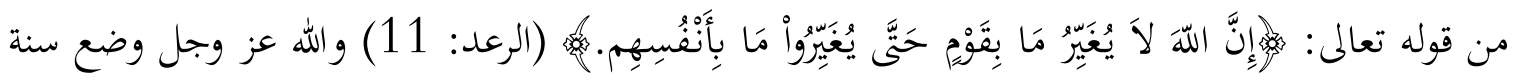
وقانوناً للتجمعات البشرية، بأنه سوف يغير ما بها إذا قام البشر بتغيير ما بأنفسهم. وقد وعد سبحانه أن يجدث التغيير في المجتمع من غنى وفقر وعزة وذلة وصحة وسقم، عندما يقوم الأفراد بمجموعهم بتحمل واجبهم في التغيير المطلوب في أنفسهم أولاً والذي يقوم بجملة على التزكية من خلال العبادة لله الحقة. ولو أن الله عز وجل أحدث التغيير قسراً دون ربط ذلك بالتغيير الذي يخص البشر، يكون ذلك مخالفاً لنص الآية، وفيه إبطال لمكانة الإنسان وأمانته ومسؤوليته، ولا يتناسب مع مقام الخلافة الذي منحه الله ل الإنسان. 
ولكن المتتبع لهذه السنة يجد بما لا يدع بجالاً للشك أن الله عز وجل قدر التغيير عبر سنة معكمة لال

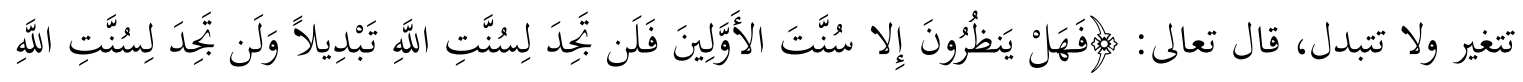

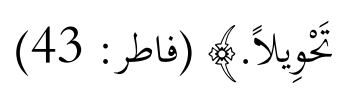

إن الله عز وجل أراد أن يضع الإنسان أمام مسؤوليته، وأن يواجه الأحداث بإرادته وقواه، وأن ينظر في الأثر الواضح لما تقوم به يداه إن خيراً فخير، وإن شراً فشر، بكتنهى حريته ومطلق إرادته.

ولن خخوض في فحوى نظرية التغيير، ولكن ما نود أن نقف عليه أن ربط عملية التغيير في تجمع بشري

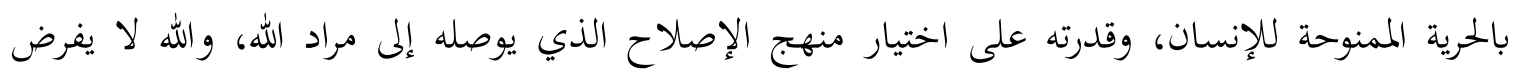

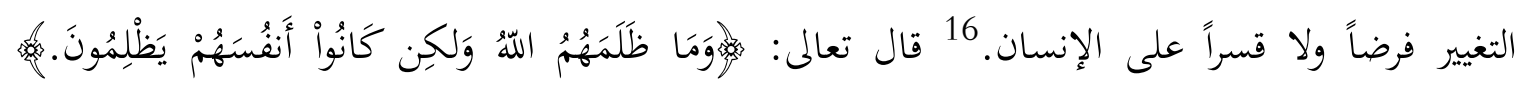
(النحل: 33)

فالإنسان يسير نو التغيير بشكل دائم، لا يتوقف ولكن العقل والشرع والعلم يدفع الإنسان للتغيير

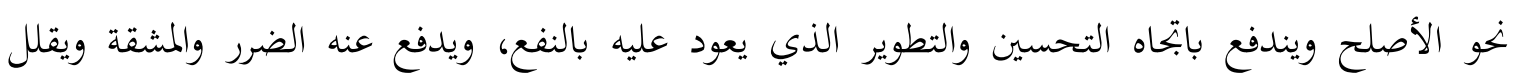

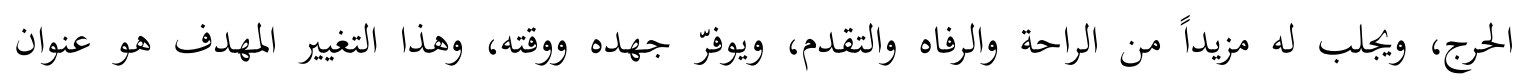

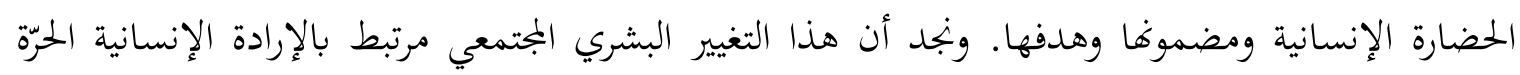
المنطلقة في البحث والتجربة والتقويم.

ثانياً :الحرية في قواعد النظام السياسي الإسلامي ومقاصده 1. - 1 - مفهوم السياسة ومقاصدها في الفقه الإسلامي

السياسة من ساس وسوس، وتأتي بعان عدة: حسن الرعاية، القيام على الشيء بما يصلحه، وحسن الإدارة والتديير. ولذلك يقال سائس الحيل: لمن يروضها ويعدها للعمل. وساس القوم: بعمنى تولي قيادقم

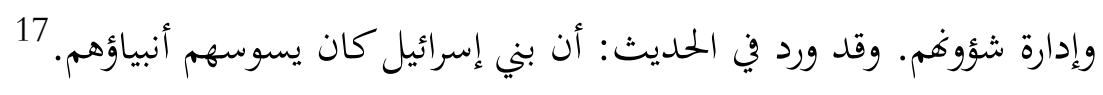

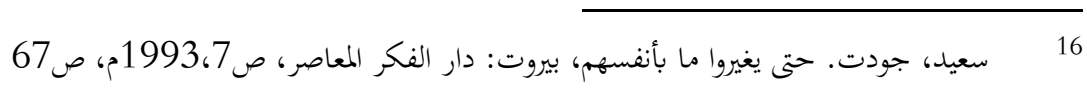

$$
\begin{aligned}
& \text { ابن منظور، لسان العرب، مادة سوس وساس، الفيروزآبادي، القاموس لاغيط. }
\end{aligned}
$$


ويرجع المعنى الاصطلاحي القانوي إلى كلمة politique"" باللغة اليونانية القديمة ويقصد بها: "فن

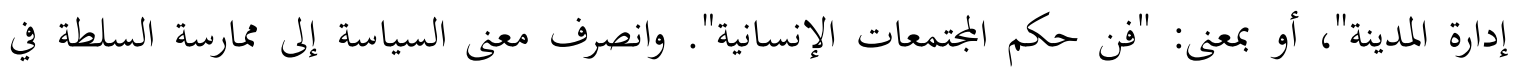
جماعة سياسية معينة.

لقد اتسع مدلول النظام السياسي باتساع نشاطه وأثره، بحيث أصبح يمتد ليشمل كل البجالات الميوية الاقتصادية والاجتماعية الفكرية، لأن الدولة أصبحت في العصر الحديث تشرف على تنظيم الاقتصاد وتوجيهه، كما أصبحت تتدخل في نشاط الأفراد والتزاماقم وحقوقهم على جميع الأصعدة. وبناء على ذلك لكافل يعرف النظام السياسي بأنه: بجموعة القواعد والأجهزة المترابطة التي تبين نظام الحكم ووسائل ممارسة السلطة،

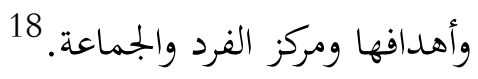

وقد وضح ابن عابدين معنى السياسة في الفقه الإسلامي بقوله: "فالسياسة استصلاح الخلق بإرشادهم

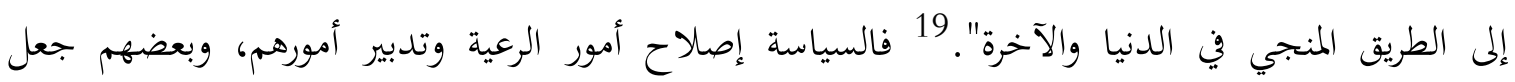
السياسة هي المحافظة على مقصد الشارع بدفع المفاسد عن الملنق. ولعل من أحسن ما نقل عن الفقهاء

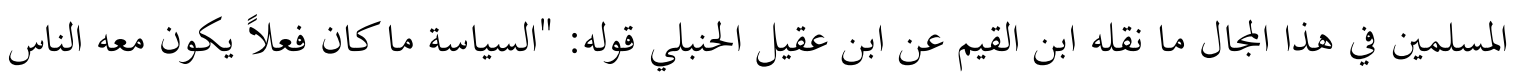

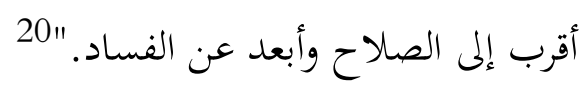

ومن خلال أقوال الفتهاء يتبين أن السياسة لديهم تعني: الإجراءات والتدابير التي تصدر عن ولي الأمر

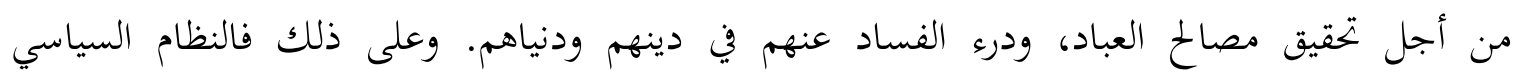
الإسلامي: بجموعة القواعد والأحكام التي تنظم شؤون السلطة العامة وعلاقتها بالأفراد، وما يتعلق باختيار الحاكم وحقوقه وواجباته، من أجل تحقيق مصلحة العباد وعصمتهم من الفساد.

بلدوي، ثروت. النظم السياسية، القاهرة: دار النهضة العربية، 1991م، 1962م، ص3 31 وما بعدها. عبد الله، عبد الغني بسيوني، النظم السياسية،

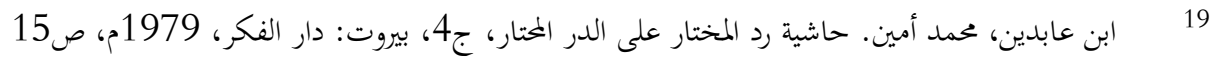

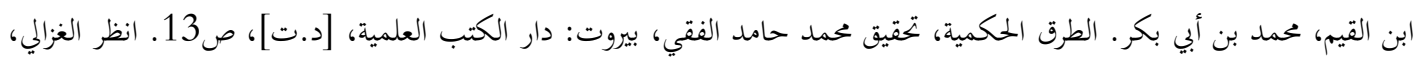
20

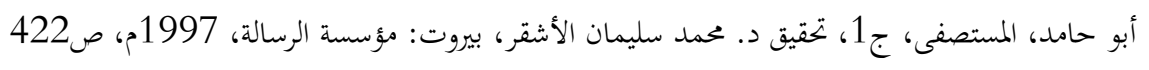


وفي ختام القول في هذه النقطة أن مدلول كلمة "سياسة" وظلالها في الفقه الإسلامي تدور حول الإصلاح وحسن التدبير، وقوة الإدارة، وتوجيه السلوك الإنساني الجماعي نخو الخير، وتوحيد الأمة ومقاومة الفساد ونفي الظلم، ووضع حد للفوضى، ووقف النزاع، وقطع دابر الخصومات، ومماية مصالح الخلق، وتمكينهم من السعي على أقواتم وتوفير الأمن لأنفسهم وأعراضهم وأموالهم. وليس كما يتبادر على ذهن الإنسان الغربي بأن السياسة معناها الخداع والظلم وطلب السيطرة، والحكم، وإيذاء الخلق، واستعمال الحيل لهزيمة الخصم، والتغاضي عن سلوك أي وسيلة لتحقيق الهدف.21

وقد أجمع الفقهاء على وجوب تنصيب إمام من أجل تنفيذ خطاب الشارع المتعلق بالمكلفين والذي لا يتم تنفيذه إلا بقوة وإمارة، مثل إقامة الحدود ورفع راية الجهاد والذب عن المسلمين وحماية ثغورهم، ووقف النزاع ورفع الخصومات وإقامة العدل بينهم، تأسيساً على فعل الرسول صلى الله عليه وسلم وأصحابه من بعده. إن أهمية النظام السياسي تتجلى بتحقيق المقاصد الشرعية التي يقوم على رعايتها، وحفظها، والتي

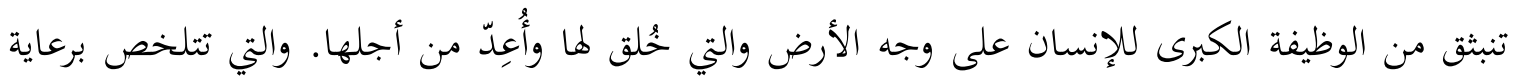
الوجود الإنساني وحفظ حياته ومقوماته، وما يتصل بذلك من حفظ النفس والنسل ودرء الاختلال والفساد عنها. تم ينتقل واجب النظام السياسي بعد ذلك لتنظيم الجهد الإنساني وتطويره وتحسينه من أجل تحقيق مهمة الخلافة في الأرض والتي تتجلى في الإعمار، وسيادة العدل ونفي الظلم وتحقيق الرفاه الإنساني وفق ضوابط الشريعة ومقاصد الشارع الكريم بلا تفريط أو إفراط. فتكون السلطة في الإسلام عبارة عن قوة موجهة لخدمة المنفعة الإنسانية العامة في الدنيا والآخرة. فالسلطة إذن وضعت لخدمة الإنسان وحفظ حياته وحفظ كرامته وإطلاق حريته وإرادته، وتوجيه طاقاته وقواه لتكون موافقة لمقاصد خلقه وإيجاده.

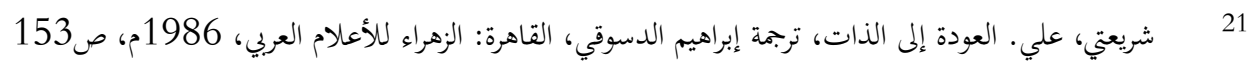

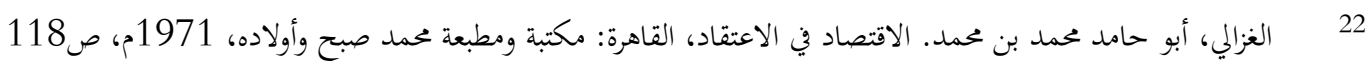


كما أن السلطة لم تشرع في الإسلام إلا من أجل استخدام القوة لمقاومة الاعتداء ونفي الظلم، ومواجهة من يستخدم القوة لاستعباد الجنس البشري وسلبهم حرياتم وتقييد إرادتم وهدر كرامتهم على مذابح النزوات الفردية والمصالح الفئوية.

وهذا ما سوف نعرضه بعد قليل بشيء من التفصيل إن شاء الله.

\section{2. العلاقة بين سلطة الحكم والحرية الإنسانية}

إن جدلية العلاقة بين السلطة والحرية من أهم مشكلات المجتمعات البشرية عبر التاريخ، وبقيت هذه العلاقة الجدلية محلاً للتظير، وتطوير الفكر السياسي، من أجل الإسهام في إيجاد حل لهذه الإشكالات المعقدة التي تظهر في تعسف صاحب السلطة في استخدامها وإساءة استعمالها، والتي تسبب في هدر الحريات ومصادرتا، وأن تكون السلطة دائماً في الجهة المناقضة للحرية والمعادية لها، مما جعل أنصار الحرية يتعرضون لبطش السلطة ومطاردة أرباب الحكم. فكيف يمكننا وصف العلاقة بين السلطة والحرية في النظام السياسي الإسلامي؟ وما هي الأسس التي نستطيع أن نبني عليها هذه العلاقة الجدلية؟

لقد سبق وأن بينّا مكانة الحرية في الإسلام وأهميتها في الفقه الإسلامي من خلال عدة نقاط أهمها: الحرية والخلقة البشرية، الحرية والتكريم والحرية ومهمة الخلافة في الأرض، الحرية والعبادة والتكليف، الحرية والتغيير.

وإذا تم مقارنة ذلك أيضاً مع أهداف النظام السياسي ومقاصده العامة، نستطيع أن نقف على العلاقة بين الحرية والسلطة في الإسلام من عدد من الأسس منها أن الحرية والسلطة يصدران عن مصدر تشريعي واحد. فالله عز وجل الذي خلق الإنسان وكونه، ومنحه العقل والحرية والعصمة والذمة، ليكون قادراً على أداء الحلافة في الأرض، كما يريد الله. فالحريات الممنوحة للإنسان هي مقاصد وأحكام شرعية، أرادها الله عز وجل وقدرها لتمكين الإنسان من إتمام التكليف الرباني على أحسن وجه، وهي تندرج في سلم الخطاب التكليفي بما يتعلق بها من مقاصد ضرورية وحاجية وتحسينية. كما أن جميع الأحكام المتعلقة بأمور الحكم والإدارة من حيث الإيجاد والتنظم والضبط وحسن التدبير هي أحكام شرعية وضعها الله عز وجل لعباده من 
أجل إعانتهم على حسن التعبد، والقيام بالتكليفات على وجهها المقصود، لتحقيق ما أنيط بالإنسان من

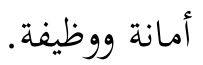

فالأحكام التي تنظم الحرية وتوجهها بابتاه تحقيق غاياتا ومقاصدها، والأحكام التي تنظم السلطة وأمور الحكم من أجل تنظيم الجهد الإنساني وتوجيه أعماله نحو تققيق مقاصد خلقه وإيجاده، كلاهما من مصدر تشريعي واحد، فالله هو الذي خلق وهو الذي وضع القواعد والأحكام كلها، فمصدر التشريع واحد وفلسفة التشريع واحدة، والقواعد التشريعية المنظمة واحدة، وهذا يؤدي إلى عدم التناقض بين السلطة والحرية، وتفي التناقض بين الأحكام التي تنظم كلاً منهما، لأن الأحكام الشرعية لكليهما جاءت من شريعة

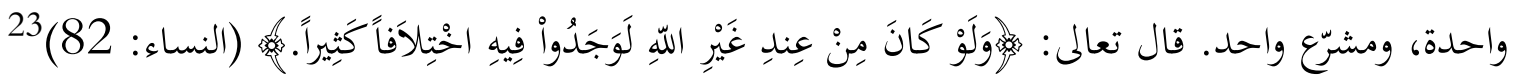
فيجب أن يكون التعامل معهما على قاعدة التوافق وعدم التعارض والتناقض. وإذا وجد تعارض ما، فهو ليس حقيقياً وإنما هو واقع في أذهان المكلفين، فيجب إزالته كما يزال التعارض بين الأحكام حسب علم أصول الفقه وقواعده المعروفة في هذا المجال، بحيث يقدم الكلي على الجزئي، ويقدم الضروري على الحاجي، والحاجي على التحسيني، والقطعي على الظني، كما يتم ا لجمع بين الأدلة بتأويل سائغ تحتمله قواعد الفقه

ويتم تطوير التدابير اللازمة في شؤون السلطة والحرية وفق الاجتهاد الشرعي المنضبط القائم على فقه المقاصد الشرعية المتفق عليها في الجملة، بكيث يكون قصد المجتهد تحقيق مقاصد الشارع الكريم أصلاً وتبعاً. 25

ومن أسس العلاقة بين الحرية والسلطة أغما تتفقان في الغايات والمقاصد الأصلية. فالدراسة السابقة لكل من مقاصد الحرية وإيجادها وحفظها وأخلاقها ومقاصد النظام السياسي العامة، تصل بنا إلى النتيجة

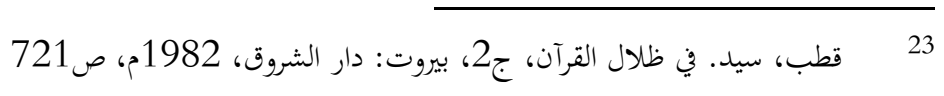

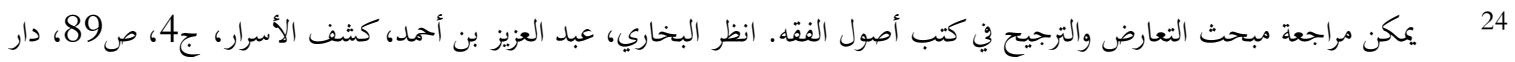

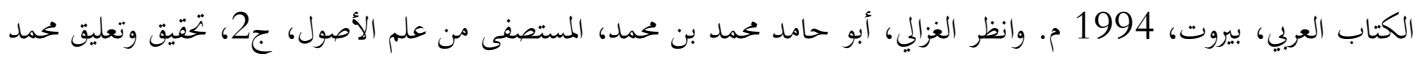

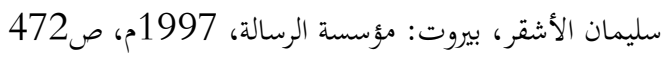
الجويني، أبو المعالي عبد الملك بن عبد الله. غياث الأمم، تحقيق مصطفى حلمي، فؤاد عبد المنعم، الإسكندرية: دار الدعوة، [د.ت]، 
القائلة أن كلاهما جاءا لتحقيق مقاصد شرعية أصلية، تندرج تحتها بجموعة من المقاصد التبعية؛ فكلاهما جاءا لتمكين الإنسان من القيام بمهمة الخلافة في الأرض، والتي شرّف الله الإنسان بحمل أمانتها وأداء رسالتها، وكلاهما جاءا من أجل إتمام عبودية الإنسان لربه على مقتضى الاختبار والابتلاء الصحيح العادل، وكلاهما جاءا من أجل إتمام تكريم الإنسان بحفظ حياته وعقله وإرادته وآدميته وذمته، وتحريره من العبودية والخوف والظلم والعوز.

والحرية تسبق السلطة في الوجود وأولوية الاعتبار؛ فالحرية وجدت مع الإنسان منذ ولادته، وجعلت من مكوناته وفطرته، فقد خلق الله الإنسان حراً وأراده كذلك، وأما النظام السياسي فقد جاء تبعاً للوجود الإنساني من أجل حفظ وجوده وتنظيم حاجاته وتوجيه جهوده، بما يمقق مصلحة العباد في المعاش والمعاد. فالنظام السياسي جاء ليحفظ حرية الإنسان ويصوفا ويوجهها لغاياتا، وينظم ممارستها بحيث يمنع التظالم والتواثب، وينفي النزاع المفضي إلى الفساد والضياع.26 والحرية ليست ناتجاً من نواتج السلطة، وليس ثثرة من ثمرات النظام السياسي، كما أها ليست منحة من صاحب السلطان والقوة، يمنحها وقتما يشاء ويقبضها وقتما يشاء، إفا منحة من الله، وهبها الخالق الكريم للإنسان المكرّم، فلا يملك أحد مصادرتها أو الانتقاص منها.

وهذا يفرض قاعدة على العلاقة القائمة بين السلطة والحرية: أن أي حكم أو إجراء تدبيري أو قانون أو نظام يصدر عن أصحاب السلطة والحكم يجب أن لا يتناقض مع حرية الإنسان ومقتضاياتها، ولا يتعرض لها بالسلب أو المصادرة، وإذا ناقضها أو صادرها فهو باطل لمناقضته قصد الشارع أصالة في إيجاد الحرية. ويقول الشاطبي: "كل من ابتغى في تكاليف الشريعة غير ما شرعت له فقد ناقض الشريعة، وكل من ناقضها فعمله في المناقضة باطل". 27 وعلى ذلك يجب أن نفقه مقصد تشريع السلطة الذي يقوم على حماية الحرية وحفظها وصيانتها، وليس على إيجادها أو منعها، لأن الإيجاد والخلق والمنح والمنع لله وحده.

26 2 ابن جماعة، بدر الدين. تحرير الأحكام في تبرير أهل الإسلام، تحقيق ودراسة فؤاد عبد المنعم، قطر: رئاسة المحاكم الشرعية، 1985م، ص ان 48 الشاطبي، أبو إسحاق إبراهيم بن موسى. الموافقات، ج2، شرح عبد الله دراز، القاهرة: المكتبة التجارية الكبرى، بيروت: دار المعرفة، 27 
إن حرية العباد وبمموع المكلفين مصدر السلطة، بمعنى أنه لا طريق لإيجاد السلطة إلا عبر الحرية، فأي بتمع بشري هو الذي يمنح السلطة لمن أراد بحريته، وينزع السلطة من يشاء بحريته. إذن فإن الحرية قيد على السلطة ومهماتها، وليست السلطة قيد على الحرية ومقتضياتا، وإذا كانت السلطة تأتي عن طريق الاختيار من الأمة، 28 فإن تأمين سلامة الحرية وحقيقة وجودها، يؤدي إلى سلطة صحيحة قائمة بواجباتها على وجه صحيح خاضعة لرقابة الحرية خضوعاً صحيحاً. فالسلطة ناتج من نواتج الحرية الإنسانية التي أنتجت نشاطاً إنسانياً منظماً، وليست الحرية نابتاً عن منتوجات السلطة ولا أثراً من آثارها.

\section{3. الحرية في قواعد النظام السياسي الإسلامي}

إن الدارس لأغلب قواعد النظام السياسي الإسلامي، يجد أها تتأسس على مبدأ الحرية، وتبنى عليها،

$$
\text { وتنطلق منها، ويمكن الإشارة إلى ذلك من خلال الوقوف على بعضها. }
$$

وأول هذه القواعد هو سلطة الأمة فالله عز وجل جعل "السلطة" لمجموع المكلفين، ولم يجعلها لشخص أو سلالة أو عشيرة أو جنس، ويلحظ ذلك من الخطاب التكليفي، فقد جاء عاماً للامة، فقد قال تعالى:

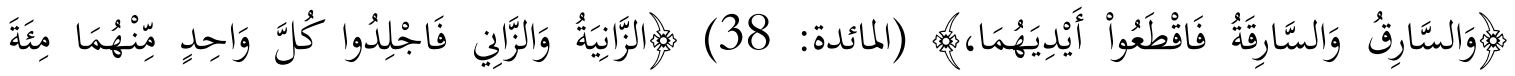

$$
\text { جَلْدَة. }
$$

مع أن الحد يقيمه شخص واحد، ولكن الخطاب الشرعي جاء ليكلف الأمة كلها في ذلك، وهي تنيب عنها من يقيم الحد. وكذلك سائر الخطابات الشرعية التكليفية. وأهم مظاهر سلطة الأمة اختيار الإمام. والإمام هو رأس النظام السياسي وهو نائب الأمة في إدارة شؤوها وحفظ مصالحها المتعلقة بالدين والدنيا، فقد عرف فقهاء السياسة الشرعية الإمامة بقولم: "الإمامة موضوعة لحراسة الدين وسياسة

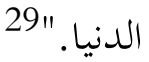

$$
\begin{aligned}
& 28
\end{aligned}
$$

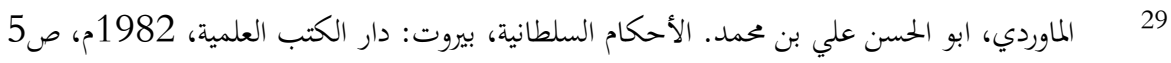


وقد أجمعت فرق الأمة وأهل الملة على أن طريق ثبوت الإمامة هو الاختيار من الأمة، باستثناء فرقة الشيعة الإمامية التي تقول إن طريقها النص من صاحب الشريعة. 30 وإن كان طريق تعيين الإمام هو الاختيار من الأمة، فإن الاختيار يعني الحرية، إذ ينتفي معنى الاختيار إذا صحب بالإكراه. لأن الاختيار يقوم على

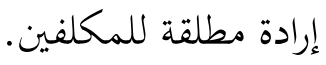

وقد تجلت هذه الإرادة بما تم التعارف عليه في الفقه الإسلامي وسمّى "البيعة"، والبيعة هي العهد على الطاعة. 31 أو بمعنى آخر هي عقد ينعقد بين الأمة والإمام، يترتب عليه حقوق والتزامات متبادلة؛ فيترتب على الأمة واجب السمع والطاعة والنصرة والنصيحة للإمام، بينما يترتب على الإمام واجب تطبيق شرع الله ومماية دينهم وأرضهم وتوزيع فيئهم وإقامة العدل بينهم إلى آخر الواجبات المفروضة. إن تكييف البيعة على أها عقد، يعني وجوب تطبيق مبدأ حرية التعاقد. 32

والقاعدة الثانية من قواعد نظام الحكم في الإسلام هي الشورى، وهي واجب مؤكد من واجبات

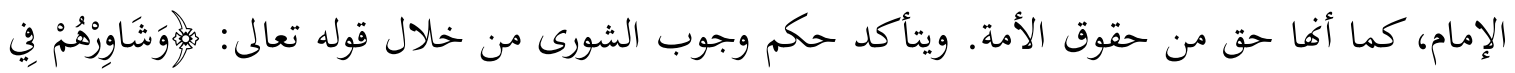

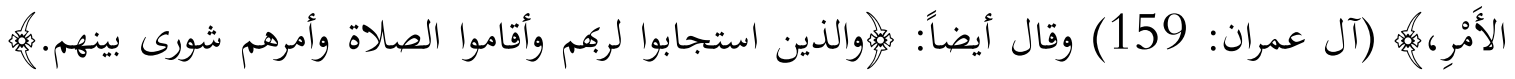
(الشورى: 36) وحقيقة الشورى كما يعرّزها الراغب الأصفهاني: "هي استخراج الرأي بمراجعة البعض إلى البعض. 33 أو كما يقول ابن قدامة: (هي استخراج الأدلة ومعرفة الحق.) 34

إن الشورى في حقيقتها عبارة عن مداولة الآراء بين أهل الرأي والخبرة والحكم في مشورة الأمة ومصالحها العامة، ولذلك نجد أن الشورى لا تتحقق إلا بتوفير الحرية، بحيث يستطيع أن يعبر كل عضو من أعضاء بجلس الشورى عن رأيه بحرية تامة. ولو انعدمت الحرية لأهل الشورى بحيث لا يستطيعون التعبير عن

$$
31 \text { 30 } 30
$$

32

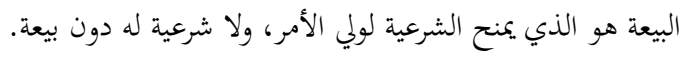

$$
\begin{aligned}
& 33
\end{aligned}
$$

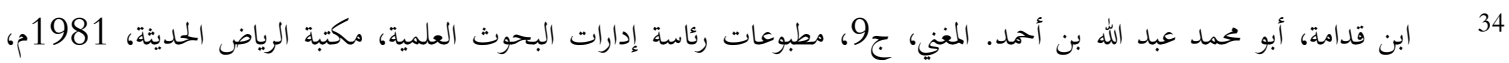


رأيهم بأمان، لانتفى معنى الشورى وانتفى مقصودها. فلا شورى بدون حرية تمكن أهل الشورى من إبداء رأيهم، وما يعتقدون صوابه دون خوف أو وجل، أو رغبة أو رهبة.

وثالث هذه القواعد هو وواجب مراقبة الحماكم وتقويمه، وذلك أصل من أصول نظام الحكم. إذلا لا يستقيم حكم بغير رقابة وتوجيه دائم من الشعب أو ممن بمثله، ورقابة الحاكم مطلوبة في الإسلام وواجبه، وليس هنا بجال بحث هذه المسألة، ولكن يمكن تأصيل رقابة الحكم وتقويمه على عدة أسس شرعية تتعلق بواجب الأمر بالمعروف والنهي عن المنكر، الذي أكدته الآيات والأحاديث الصحيحة، قال تعالى: مارَ وقال رسول الله صلى الله عليه وسلم: "والذي نفسي بيده لتأمرنّ بالمعروف، ولتنهون عن المنكر أو ليوشكن الله أن يبعث عليكم عقاباً منه، ثم تدعونه فلا يستجاب لكم." ثمرات واجب الأمر بالمعروف والنهي عن المنكر والذي فيه حفظ الأمة وديمومتها وإبعادها عن الهلاك؛ 36 لأن الأمة التي تصل إلى حالة لا تستطيع أن نقول للظالم يا ظالم، فقد تودع منها، بمعنى قد أفلت وأفل نجمها. كذلك فإن النصيحة، 37 سمة من سمات المجتمع المسلم الذي ينصح الأفراد بعضهم بعضاً، وتنصح الأمة أمامها وينصح الإمام أمته. والنصيحة ما هي إلا تمحيض الخير للمنصوح وإرادة الخير له من كل وجه، كما أن النصيحة تعتبر جوهر التدين وحقيقته، فقد ورد في الحديث الصحيح عن الرسول صلى الله عليه وسلم قوله: "الدين النصيحة، قلنا لمن يا رسول الله، قال: لله ولرسوله ولكتابه ولأئمة المسلمين وعامتهم." "38 ويعتبر هذا الحديث من الأحاديث الشاملة التي تتوي معان كثيرة على درجة كبيرة من الأهمة، وقد وضح

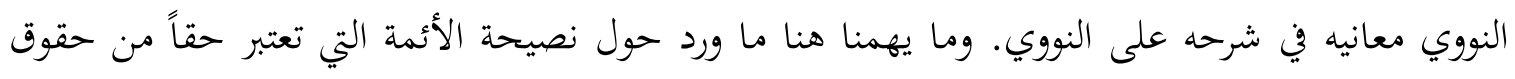
الأمة، وواجباً من واجباتما.

$$
35
$$

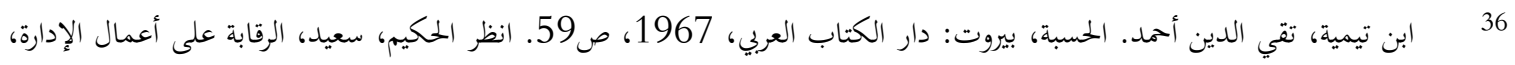

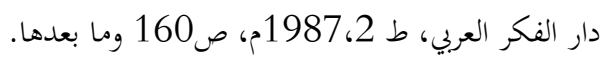

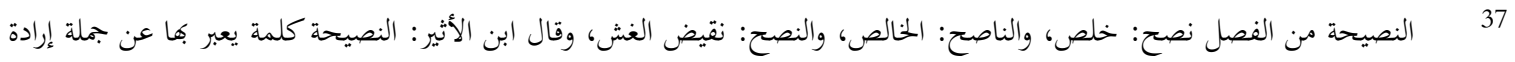

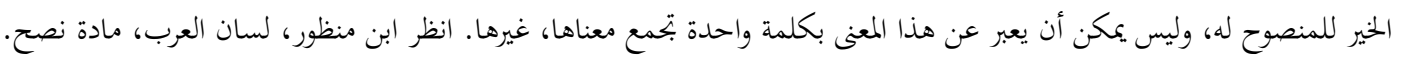

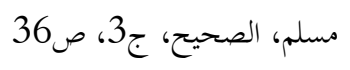


ويمثل فعل الصحابة رضوان الله عليهم أساساً شرعياً ثالثاً لرقابة الحكام، فقد خطب الخليفة الأول أبو بكر رضي الله عنه بعد توليه الخلافة في أول خطبة له: "لقد وليت عليكم ولست بخيركم، إن أحسنت فأعينوني، وإن أسأت فقوموني..."39 كما قال الخليفة الثاني عمر بن الخطاب رضي الله عنه: "إذا رأيتم فيّ

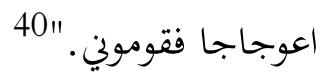

نستنتج مما سبق أن رقابة الحاكم وتقويمه أصل من أصول النظام السياسي الإسلامي، وأن هذا الأصل يستند إلى الحرية التامة للأمة فلا تتحقق الرقابة إلا بجو مفعم بالحرية، يستطيع المسلم أن يصدع برأيه بقوة، ويأمر بالمعروف وينهى عن المنكر بجرأة، وينصح بما يراه صواباً وحقاً ولا سبيل إلى ذلك إلا بالحرية.

ونظام الحكم بما يملك من سلطة يتوجب عليه توفير هذه الحرية وحفظها وصيانتها، حتى يتم تحقيق

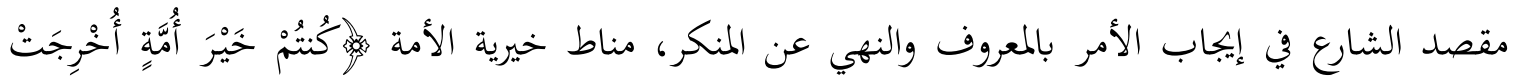

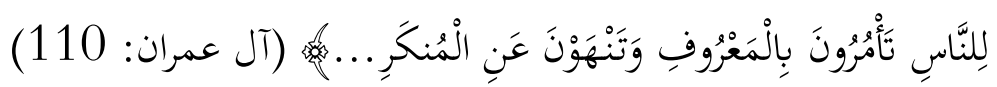

\section{4. الحرية في مقاصد النظام السياسي الإسلامي وواجباته}

تُعدُّ رعاية الوجود الإنساني وحفظ مقوماته وكرامته من أهم مقاصد النظام السياسي وأكثرها أولوية وذلك من أجل حفظ مقاصد الخالق الكريم في خلقه، وتحقيق حكمته. ويكون حفظ الإنسان بحفظ حياته وتأمين متطلبات استمرارها وحفظ عقله وحريته وإطلاق إرادته، لأنه لا سبيل لاكتمال الوجود الإنساني إلا .

وحفظ حرية الإنسان تظهر في كل عمل أو تدبير سياسي لتحقيق هذه الغاية، فلا سبيل لحفظ الحياة إلا بإزالة كل أنواع التهديد التي يشعر بها الإنسان عل نفسه وأهله وعياله وماله. والنظام السياسي معني بتحقيق هذا الهدف، بما يملك من سلطة وقوة؛ لأن الخوف بحقيقته ما هو إلا عامل من عوامل التهديد التي تسلب الإنسان حريته التامة. ومن هنا فقد عني الإسلام بتدبير النظام العقابي لكل من يعتدي على حياة

$$
39
$$

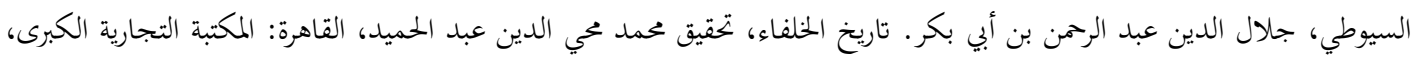

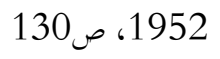


الإنسان ومقومات عيشه وما الحدود والقصاص إلا لتحقيق هذه الغاية. ومن أهم وظائف النظام السياسي إقامة الحدود التي تتعلق بالاعتداء على الناس في أنفسهم وأعراضهم وأمواهم. 41

ومن مقومات الوجود الإنساني تسهيل عمل الإنسان على الكسب والكدح من أجل تحصيل قوته وقوت عياله. وهذا يقتضي توفير الحرية الكاملة لكل قادر على الكسب أن يسير في مناكب الأرض ابتغاءً لفضل الله. وأن يملك حرية اختيار العمل واختيار الحرفة، واختيار المكان والجهة ولون الضرب في الأرض، في حدود ما شرع الله وأباح. 42 ويتضح في هذا المجال تشريع الحرية الواسعة في طلب المباحات والتنعم في

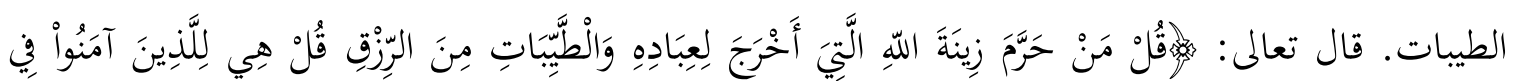

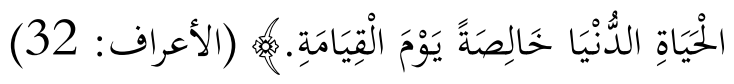

ولذلك نؤكد أن مهمة السلطة التشريعية في النظام السياسي الإسلامي أن تتوجه نهو إفساح الحرية الشريعية للناس في زيارة ثروقم وتنمية إنتاجهم عبر الطرق المشروعة، ويتأسس ذلك على القاعدة المأخوذة من

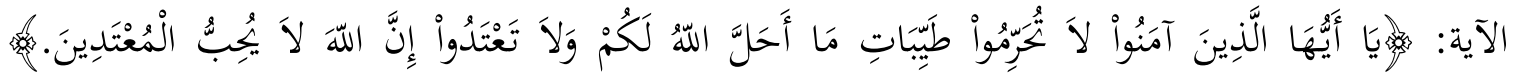
(المائدة: 87)

ويسعى النظام السياسي إلى توفير الأمن الحياتي والأمن الغذائي والأمن السياسي بكل أنواعه وأقسامه، بحيث يسعى إلى بناء الحرية التامة. ولقد كان العقاب الذي شرع من أجل مقاومة الترويع والإرهاب في

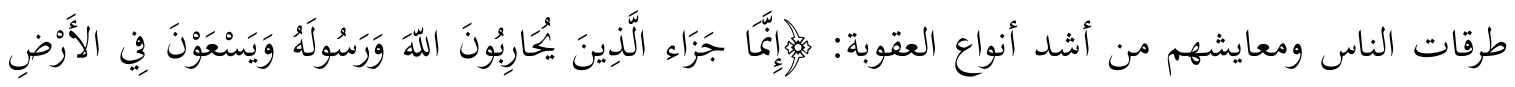

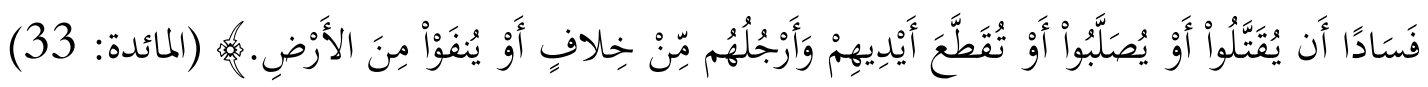
إن مهمة نظام الحكم الكبرى يجب أن تتوجه إلى حماية حرية العباد الكاملة، التي تعلهم قادرين على السعي والتنقل دون خوف أو رعب أو إرهاب من كل من يملك القدرة على سلب حريات الناس بغير وجه

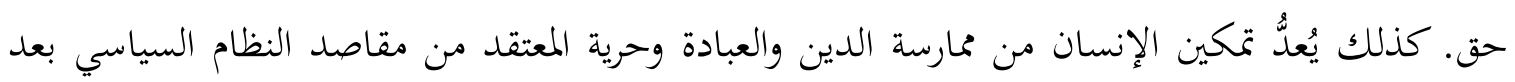
حفظ الوجود الإنساني ورعايته كما أراد الله أن يجقق حرية الدين والعبادة والعقيدة.

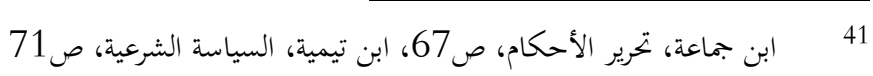

$$
\begin{aligned}
& 42
\end{aligned}
$$


فالوجود الإنساني ابتداء كان من أجل العبودية الحقة، بمعناها الشامل الذي وضحه ابن تيمية بقوله: العبادة مجموع الأفعال والأقوال الصادرة عن الإنسان. فالنظام السياسي وما يملك من سلطة يجب أن يهدف إلى تمكين الإنسان من التدين والقيام بالعبودية لتحقيق ما هو مركوز في فطرته وطبيعته وجبلته ونوازعه، والتي تتحقق من خلالما إنسانيته. 43 ولا يكون التدين ولا تتحقق العبودية إلا بتوفير الحرية الإنسانية الكاملة،

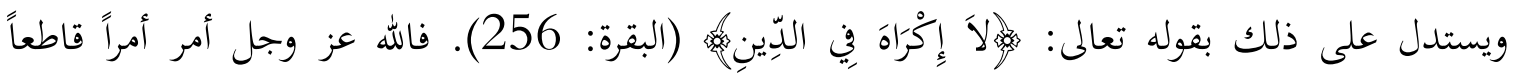
محماً، لا يحتمل نسخاً ولا خلافاً، أن الدين لا يكون بالإكراه وسلب الإرادة ومصادرة الحرية.

وإن حقيقة العبودية هي أضخم حقيقة كونية لا تستقيم الحياة إلا بها وبدون إدراكها واستيفائها تنقلب الحياة إلى فساد وبؤس وضنك، ومن هذه الحقيقة يستمد الإنسان وجوده ووظيفته، وكرامته، وإحساسه، ومشاعره وقيمة أفعاله ونشاطاته، ويبتعد عن العبثية واللهو، ويتخلص من القلق والتوتر والضياع، ويشعر بارتباطه بخالق الكون وما فيه، ويحس برعايته وفضله، وصلته الدائمة وعنايته الفائقة.

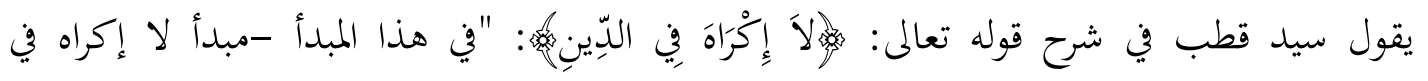
الدين- ينجلي تكريم الله للإنسان، واحترام إرادته وفكره ومشاعره، وترك أمره لنفسه، فيما يختص بالهدى والضلال وفي الاعتقاد وتحميله تبعة عمله وحساب نفسه، وهذه هي أخص خصائص التصور الإنساني. إن حرية الاعتقاد هي أول حقوق الإنسان، التي يثبت له بها وصف "إنسان"، فالذي يسلب إنساناً حرية الاعتقاد إنما يسلبه إنسانيته ابتداءً، ومع حرية الاعتقاد حرية الدعوة والعقيدة، والأمن من الأذى والفتنة، وإلا فهي حرية بالاسم لا مدلول لها في واقع الحياة."44

ومن هنا يمكن القول إن "الدين الإسلامي" وحده الذي ضمن حرية التدين للمخالفين نصاً وديانةً، فالدين نفسه يأمر أتباعه أن يتركوا الناس وما يدينون. ولذلك يعتبر الدين الإسلامي ضمانة اعتقادية وعملية لحرية الأديان المختلفة، ولكن أكثر الناس لا يعلمون، إذ ليس من المعقول أن الإسلام يستنكر على الذين يقهرون الناس ويصادرون حريتهم في العبادة، ثم يعمد إلى قهر الناس وسلبهم حرياتم إذا استلم السلطة!

$$
\begin{aligned}
& 43
\end{aligned}
$$

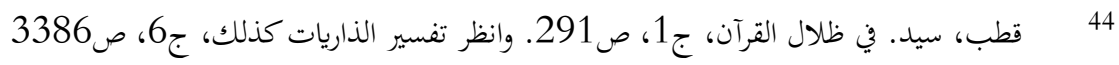


والقيام على مهمة الخلافة في الأرض وتحقيق العمران ونشر العلم من المقاصد الأخرى للنظام السياسي الإسلامي وما يملك هذا النظام من سلطة وقوة إنما تعمل على تسهيل مهمة الإنسان ووظيفته الكبرى في

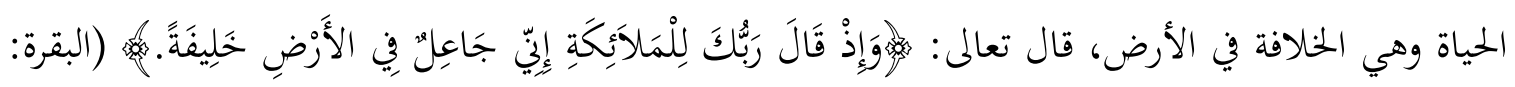
30) وقد أسلفنا أن مهمة "الخلافة" اقتضت اختصاص الإنسان بالعقل والحرية، لأن بقية الكائنات مقهورة على القيام بأعمالها ووظائفها، وأما الإنسان فقد وهبه الله العقل واختصه بالحرية ليتمكن من التفاعل مع موجودات الكون بالمبادرة والخببرة والعمل والنظر والبحث والتقويم والاختبار.

فالإنسان الذي سلبت إرادته وتعطلت قواه، لا يستطيع تحمل مسؤوليته ولا القيام بوظيفته، ويصبح إنساناً كلاً، كائناً مقهوراً كبقية الكائنات التي تتتاج إلى توجيه وتنظيم وتفعيل من غيرها. لقد أراد الله لهذا الإنسان أن يكون سيداً، وسخر له الأسباب التي تمكنه من حمل الرسالة وأداء الأمانة. و إن النظام السياسي وما يملك من سلطة يتحمل عبء المسؤولية في إيجاد الحرية الكاملة التي تكن الإنسان من حمل أمانته وأداء رسالته بقوة وإرادة وعزم وقدرة. وعلى النظام السياسي أن يزيل العوائق التي تحول بين الإنسان وأداء مهمته العظيمة ووظيفته الربانية الكريمة اتي تعطيه معنى الإنسانية ومعنى الحياة

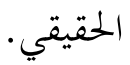

إذن نستطيع القول: إن السلطة شرعت من أجل وحماية الحرية وحفظها ودرء ما يقهرها، وإزالة كل عائق أمام انطلاقتها وتسهيل أدائها، على النحو الذي يريده الخالق الحكيم، بدفعها نخو تحقيق الإعمار ونشر الرفاه وتعميم الخير على جميع مخلوقات الكون.

إن النظام السياسي يهذف إلى توجيه السلوك البشري وتنظيم الجهد البشري في إيجاد هضة عمرانية راقية، تسهل حياة الإنسان، وتوفر وقته وجهده، وتحقق الرفاه المعيشي والرخاء الاقتصادي. وهذا يتطلب نشر العلم وتحفيز العقل على الإبداع والابتكار والتنافس في تسخير ما سخره الله في الخير والنفع. 
كما أن النظام السياسي يجب أن يتولى عبء تحرير العقول من الخرافات والأساطير، والتقليد الأعمى، كيما ينطلق العقل باحثاً مستشكفاً وفق المنهج العلمي الأصيل الذي رسمه القرآن الكريم وذلك عبر تبني

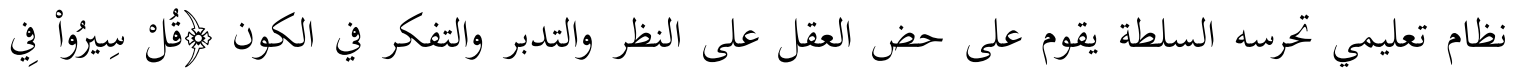

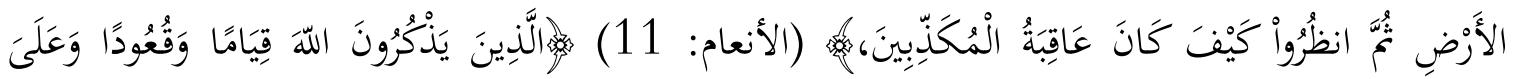

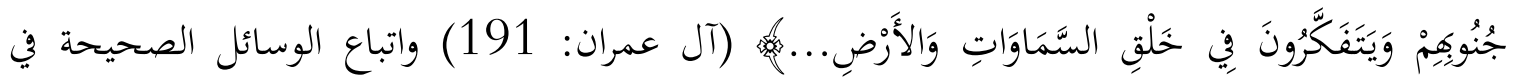

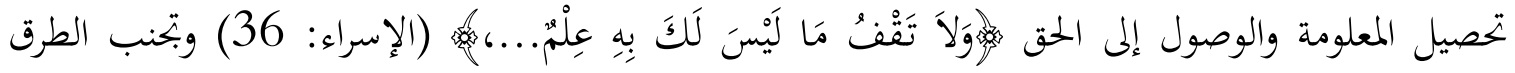

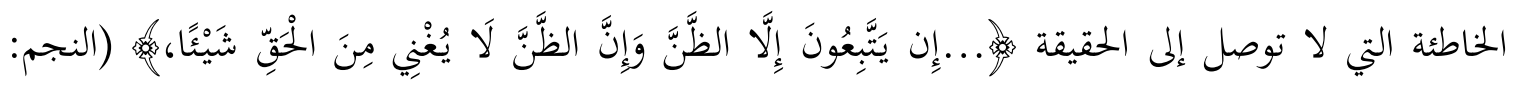

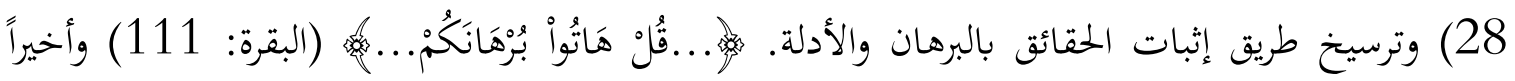

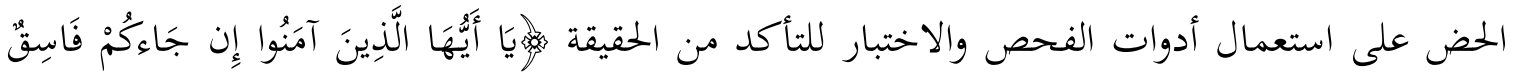

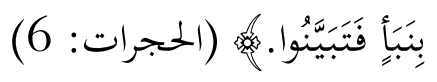

إن نشر العلم، وطلب العلم والتعليم، وتشجيع الإبداع، وإطلاق العقل من جميع القيود والأسر التي تحد من التفكير لا تتم إلا بحال ينعم الناس فيه بالحرية التامة التي يسهر النظام السياسي على توفيرها وحفظها وصيانتها بما يملك من سلطة وقوة موجهة في بجال الخير والتي تتمثل بأوجه كثيرة منها حرية العلم والتعلم، واختيار التخصص الذي يناسب طبعه ويوافق رغبته في أي بجالات العلم النافعة على صعيد الكون

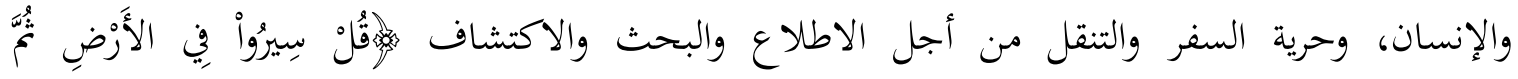

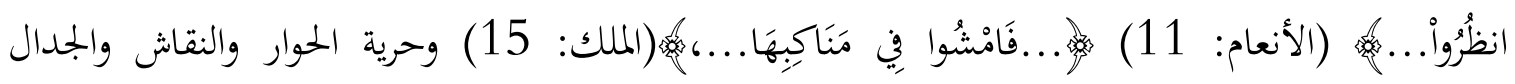

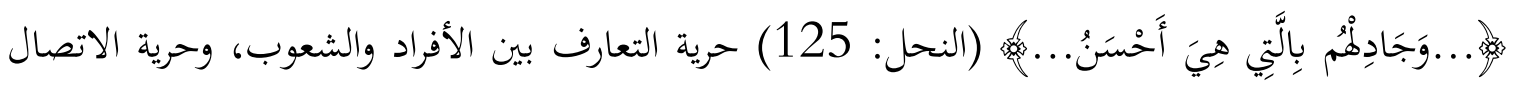

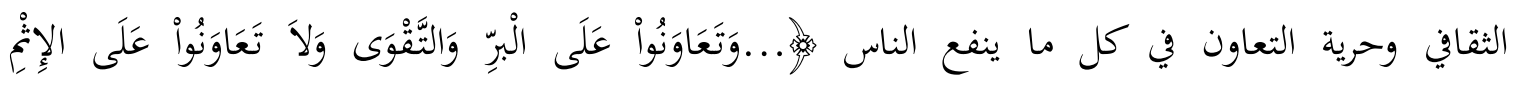

$$
\text { وَالُْعْدَوَانِ... }
$$

ومن أهم ما اتفق عليه العلماء في تحديد مقاصد النظام السياسي هو إقامة العدل ونفي الظلم؛ لأن العدل ضمانة استمرار الوجود الإنساني الحقيقي الذي يخلو من الفساد والظلم والنزاع والتواثب. 45 قال تعالى: 


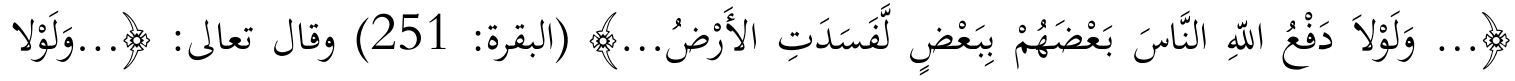

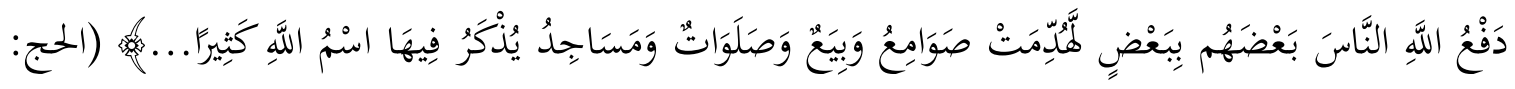

ويقصد هنا أنه لولا ما سخر الله عز وجل من تمكين بعض العباد بدفع الظالم ووقف الاعتداء، لأدى ذلك إلى الفوضى والدمار والفساد المفضي إلى الهلاك. ويتجلى مقصد إقامة العدل ونفي الظلم بحفظ حرية العباد وصيانتها من الاعتداء والتجاوز من أصحاب القوة والسلطان. 46 يقول بدر الدين بن جماعة: "وقد اتفقت شرائع الأنبياء وآراء الحكماء والعقلاء أن العدل سبب لنمو البركات ومزيد من الخيرات، وأن الظلم والجور سبب لخراب الممالك واقتحام المهالك ولا شك عندهم في ذلك."47 ويقول ابن القيم: "فان الله سبحانه أرسل رسله وأنزل كتبه ليقوم الناس بالقسط وهو العدل الذي قامت به الأرض والسموات. فإن ظهرت أمارات العدل وأسفر وجهه بأي طريق كان، فثم شرع الله ودينه."48

وما العدل في حقيقته إلاّ إقامة الحرية، وتمكين العباد من القيام بتكاليفهم، وعباداتم، وتسهيل معايشهم، وإزالة القهر والخوف الذي ينغص عيشهم وحياتم، أو يحدّ من سعيهم وكسبهم، أو يحرمهم مما أباح الله لهم من الطيبات والزينة.

ومما يستحق النظر أيضاً في علاقة النظام السياسي بالحريّة مسألة الجهاد، إذ أن النظام السياسي ينظم أمر الجهاد من أجل حماية الحرية. وربما تكون مسألة القتال واستخدام القوة من أهم القضايا التي تستحق البحث للوقوف على تأثر الحرية بهذا المبدأ الذي يؤدي إلى استنتاج متسرع أن استخدام القوة مناقض للحرية. ولكن التأني في الوقوف على مشروعية القتال ومقاصده وأهدافه يتبين بوضوح أن الجهاد شرع من أجل تحرير الناس، وليس من أجل مصادرة الحريات وقهر العباد. فهدف الجهاد ابتداءٌ مشتق من هدف

46 يقول الطرطوشي: "إنه لولا أن الله تعالى أقام السلطان في الأرض بدفع القوي عن الضعيف، وإنصاف المظلوم من ظلمالم، لتواثب الناس

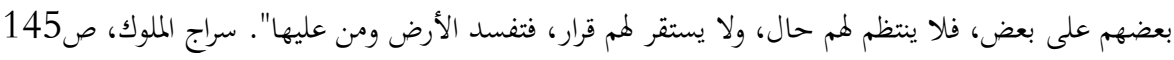

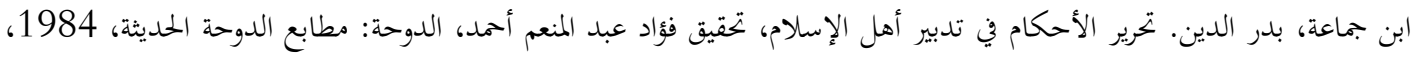


وجود المسلم الذي يقوم على رفع كلمة الله وذلك بتبليغها إلى البشر بحرية، وهذا يقتضي عرض دعوة الله على الناس في جو تسوده الحرية بحيث يستطيعون سماع ما يعرض وفهمه ومناقشته ومن ثم القبول أو الرفض. والقتال يقصد منه رفع القهر والإكراه عن الناس حتى يقولوا كلمتهم بحرية، ومصدر القهر يكون دائماً من أصحاب السلطة التي يتمسك بها أصحاب المصالح الذين يمنعون الناس من سماع كلمة الحق أولاً ويمنعوفم من الاستجابة لما ثانياً بالقوة والقهر والعنف والكبت والإكراه.

ولذلك روي عن ربعي بن عامر الذي كان في جيش سعد بن أبي وقاص الذي ذهب لفتح العراق، أنه قال مجيباً على سؤال رستم: ما الذي أتى بكم إلينا؟! قال: جئنا لنخرج الناس من عبادة العباد إلى عبادة الله

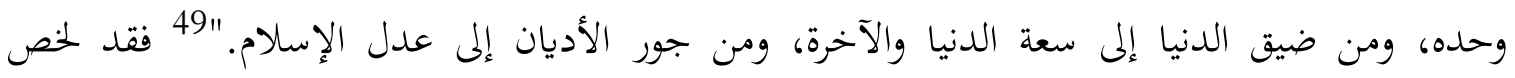
أهداف الجهاد بعرض دعوة الله على الناس، ليؤمن من يشاء ويرفض من يشاء دون قهر أو قمع أوكبت،

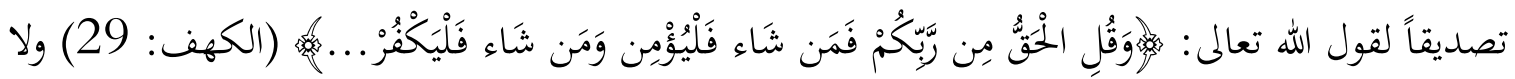

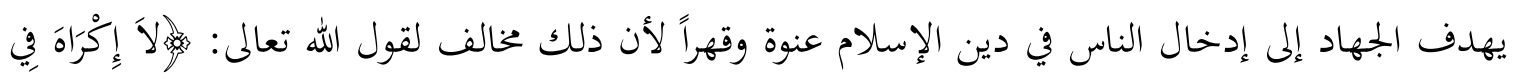
الدّّينِ.ه. (البقرة: 256) وإنما يهدف إلى إزالة كل عوامل القهر والتسلط التي تمنع الناس أن يكونوا أحراراً في اتباع ما يرونه حقاً بمض إرادقم، وفكرهم وما توصلت إليه عقولم، بالحوار والجدال بالتي هي أحسن. وأخيراً فإن النظام السياسي يحمي منظومة القيم الإسلامية ويحرسها. ولا يكتمل المفهوم النظري لبحث الحرية في النظام السياسي إلاّ بإتمام هذه الجزئية المتعلقة بدور النظام السياسي في حفظ منظومة القيم، التي تشكل العمود الفقري لشخصية الإنسان المعنوية. وسبب ذلك أن كل المباحث والمطالب السابقة قامت على فكرة هدف النظام السياسي بحراسة حرية الإنسان وصيانتها، وهذا يؤدي إلى القول: إن الحرية الممنوحة للإنسان قد تؤدي إلى التعارض والتناقض والفوضى، مما يكون سبباً في الهلاك والفساد! 
والحرية الممنوحة للإنسان من الخالق، وضعت لحكمة وتحقيق غاية، فلا يصلح استخدامها الاّ فيما وضعت له، ولذلك يقول الشاطبي: الإنسان مستخلف عن الله في نفسه وأهله وماله، وكل ما وضع تحت يده، فكان المطلوب منه أن يكون قائماً مقام من استخلفه بأن يجري أحكامه ومقاصده بجاريها. 50 والله سبحانه الذي وهب الحرية للإنسان وجعلها مركوزة في فطرته هو الذي وضع أحكامها وضوابطها وغاياتما وأهدافها، وكيفية استعمالها، وعاقبة ما يترتب على ممارستها من مآلات، وهو وحده الذي يعلم صلاحها وفسادها. والشريعة تؤخذ كلها جملة، فلا يصلح أخذها أجزاء وتفاريق، وأن يأخذ المكلف ما يشاء ويدع ما يشاء، ولذلك فإنَّ صلاح الإنسان متوقف على كمال الامتثال لعموم الشريعة،

وبناء على ما سبق، فان الله عز وجل الذي خلق الإنسان ووهبه العقل والحرية، هو الذي أمر ببناء شخصية الإنسان المعنوية، عبر بناء منظومة القيم الثابتة، التي تشكل المرجعية الاجتماعية الموحّدة، وهذه القيم ثابتة ومستقرة، لا تتغير ولا تتبدل، ولا تخضع لتغيرات الزمن وعاديات الدهر، لأغها مستمدة من شرع الله وليس من وضع الإنسان وما يكتنفه من نقص وما يعتوره من ظروف متغيرة.

وهذه القيم تمثل القطعيات التي جاءت على شكل قواعد عامة وكليات شاملة، وأصول ثابتة، لا اختلاف فيها، وليست محلاً للاجتهاد، وهي مرجع الخلاف وأصل الاجتهاد لكل ما يجوز الاجتهاد فيه، فيجب رد الفروع إلى الأصول، والظنيات إلى القطعيات والجزئيات إلى الكليات، والأحكام إلى المقاصد والغايات. كما أن هذه القيم توجه سلوك الإنسان وتنظمه، وتّذبه وبتعله يسير في محصلة نافعة ترتد على الفرد والجماعة بالخير والنفع، وتضبط التعامل القائم بين الأفراد فيما بينهم، ونضبط تعاملهم مع كل عناصر الوجود. فهي تنظم تعامل الفرد مع خالقه، وتنظم تعامله مع نفسه وذاته وتنظم تعامله مع الآخرين والمجتمع المخيط من أقرباء وأصدقاء وأعداء، وتنظم تعامله مع مخلوقات الكون كافة من نبات وحيوان وماء وغاز، وتنظم تعامله مع الزمن، وعالم الغيب. ويتشكل من ذلك ثقافة عامة شاملة متوازنة يتسم بها أفراد المجتمع 
على العموم والغالب، قائمة على مصادر الشريعة والاعتقاد، وما يلحقه من دور العقل الجمعي المبني على

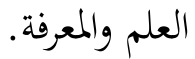

وفي ختام هذه الجولة السريعة نصل إلى أمرين مهمين: أولهما أنّ حرية الإنسان الفردية تنضبط لديه

برقابة داخلية عبر بناء ذاته، عقلاً ونفساً وروحاً وجسماً وفق قواعد الشريعة التي تراعي الخلقة الإنسانية والتكوين الآدمي (الفطرة). والأمر الثاني أنّ الحرية الاجتماعية تنضبط عبر بناء منظومة قيم معرفية تصنع ابتحاهات وسلوكات جماعية متفقة، عبر ثقافة عامة غالبة، تنفي التناقض والتعارض، وتحترم الاختلاف المشروع والإيجابي الهادف.

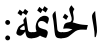

تمثل الحرّية مرتبة متقدمة في مقاصد الشريعة الإسلامية، ويمكن إضافتها إلى المقاصد الضرورية، إذ هي عنصر مركوز في الفطرة البشرية، كما العقل، وتعد مناط الابتلاء الرباني القائم على إطلاق الإرادة الإنسانية. والحرية منحة من الله للإنسان. وهي من تكريم الله للإنسان المكلف بالعبادة والخلافة في الأرض، وهي خاضعة لأحكام الشريعة حفظاً ومقصداً وممارسة. وقد وجد النظام السياسي من أجل رعاية الوجود الإنساني وحفظ حياته وعقله وحريته، وتنظيم الجهد الإنساني من أجل تحقيق المهمة الإنسانية الكبرى في الكون. وتنبثق الحرية والسلطة من مصدر تشريعي واحد، وتنظمهما شريعة واحدة، ويتفقان في الغاية الكبرى والمقاصد العامة، فلا تناقض بينهما ولا تعارض ولا تصادم.

وقد وجدت الحرية مع الإنسان قبل إيجاد السلطة، فالسلطة تخدم الحرية وتحفظها وترعاها، وتعمل على تحقيق حكمتها التشريعية، فالسلطة مقصودة تبعاً، وما قصد تبعاً يجب أن لا يقود على الأصل بالإبطال.

وتتجلى آثار الحرية في قواعد النظام السياسي الإسلامي في معظم مقاصده وواجباته، وهي تشكل معياراً على أداء صاحب السلطة والحكم، فمن أهم مقاصد النظام السياسي الإسلامي حفظ الحرية الإنسانية ودرء الاختلال عنها بما يملك من قوة السلطة، من أجل تحقيق وظيفتها ومقصدها التشريعي العام. 
وكشفت هذه الدراسة عن بعض الأسئلة والإشكاليات التي تحتاج إلى مزيد من البحث والدراسة، ومن

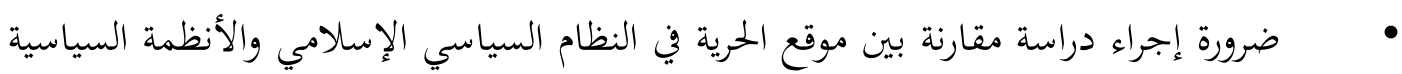
الأخرى، المنبثقة من النظرة الاشتراكية والنظرة الرأسمالية من حيث الفلسفة التشريعية والقدرة

على معالجة إشكالية العلاقة بين السلطة والحرية.

• • في الفكر، في إطار إنساني عام، ينتفي فيه الظلم والقهر والإبعاد والاستعباد.

ويجدر في ختام هذا البحث توجيه توصية إلى المنظمات والحركات العاملة في مجال نشر الإسلام

وتمدف إلى استئناف الحياة الإسلامية، أن تقدم النظام السياسي الإسلامي بجوهره الحقيقي الهادف إلى حفظ حرية الإنسان وصيانتها، ودرء كل عوامل القهر المنبثقة من السلطة، بحيث يشعر كل فرد يعيش في الكرة الأرضية أن الإسلام ميمثل الإطار السّلمي الحقيقي لكل بني البشر. 